\title{
Structural Domains of the CB1 Cannabinoid Receptor That Contribute to Constitutive Activity and G-Protein Sequestration
}

\author{
Jingjiang Nie and Deborah L. Lewis \\ Department of Pharmacology and Toxicology, Medical College of Georgia, Augusta, Georgia 30912
}

\begin{abstract}
The CB1 cannabinoid receptor is a constitutively active receptor that can sequester $\mathrm{G}_{\mathrm{i} / \mathrm{o}}$-proteins and prevent other $\mathrm{G}_{\mathrm{i} / \mathrm{o}^{-}}$ coupled receptors from signaling (Bouaboula et al., 1997; Pan et al., 1998; Vasquez and Lewis, 1999). G-protein sequestration occurs because the population of $\mathrm{CB} 1$ cannabinoid receptors exists in both an inactive $G$-protein-precoupled $R G_{G D P}$ state and a constitutively active $R^{\star} G_{\text {GTP }}$ state. We tested the hypothesis that the distal $\mathrm{C}$-terminal tail acts to prevent $\mathrm{G}$-protein activation. We found that truncation of the distal $\mathrm{C}$-terminal tail of the CB1 receptor (CB1-417) enhanced both the constitutive activity and the ability of the receptor to sequester G-proteins. In addition, we tested the hypothesis that the conserved aspartate (D2.50) in the second transmembrane domain of the CB1 cannabinoid receptor is crucial for constitutive activity and G-protein sequestration. We found that the mutation of aspar-
\end{abstract}

The discovery of the CB1 cannabinoid receptor (Howlett and Fleming, 1984; Howlett, 1985; Matsuda et al., 1990) and the demonstration that cannabinoid receptors are the most abundant G-protein-coupled receptor in the brain (Herkenham et al., 1990) stimulated questions about its physiological function. The active ingredient in marijuana, $\Delta^{9}$-tetrahydrocannabinol, binds to the CB1 receptor and is effective in alleviating pain and nausea, stimulating appetite, and affecting memory and mood. Endogenous cannabinoid ligands, anandamide and 2-arachidonylglycerol, are made in response to neuronal activity (Devane et al., 1992; Di Marzo et al., 1994, 1998; Stella et al., 1997) and act as fast retrograde messengers (Kreitzer and Regehr, 2001; OhnoShosaku et al., 2001; Wilson and Nicoll, 2001). CB1 receptors are found in high density in GABAergic neurons (Matsuda et al., 1993; Tsou et al., 1998), and CB1 receptors inhibit GABA release (Katona et al., 1999; Hajos et al., 2000; Hoffman and Lupica, 2001; Wilson and Nicoll, 2001) by inhibiting $\mathrm{Ca}^{2+}$ channels (Mackie and Hille, 1992; Mackie et al., 1995; Pan et al., 1996; Twitchell et al., 1997; Shen and Thayer, 1998; Sullivan, 1999).

The CB1 cannabinoid receptor is unusual because it is constitutively active and therefore is able to transduce a biological signal in the absence of ligand (Bouaboula et al., 1997; Landsman et al., 1997; MacLennan et al., 1998; Pan et al., 1998; Coutts et al., 2000). The CB1 receptor is also unusual in that it can sequester $\mathrm{G}_{\mathrm{i} / \mathrm{o}}$-proteins and prevent other $\mathrm{G}_{\mathrm{i} / \mathrm{o}}$-coupled receptors from sig-

Received June 7, 2001; revised Aug. 31, 2001; accepted Sept. 5, 2001.

This work was supported by Grant DA10350 from the National Institute on Drug Abuse. We thank Dr. Kenneth Mackie for CB1-D164N, Dr. Tom I. Bonner for CB1, and Sanofi-Synthélabo (Paris, France) for SR141716A.

Correspondence should be addressed to Dr. Deborah L. Lewis, Department of Pharmacology and Toxicology, Medical College of Georgia, 1120 15th Street, Augusta, GA 30912. E-mail: dlewis@mail.mcg.edu.

Copyright (ㄷ) 2001 Society for Neuroscience $0270-6474 / 01 / 218758-07 \$ 15.00 / 0$ tate to asparagine (CB1-D164N) abolished G-protein sequestration and constitutive receptor activity without disrupting agonist-stimulated activity. We conclude that the CB1-D164N mutation and the $\mathrm{C}$-terminal truncation shift the population of receptors in opposite directions. The CB1-D164N mutation shifts the receptor into an inactive $R$ state upcoupled from G-proteins, whereas the C-terminal truncation (CB1-417) shifts the receptor into the active $R^{*} G_{G T P}$ state. Thus the distal C-terminal tail acts to constrain the receptor from activating G-proteins, whereas the aspartate (D2.50) in the second transmembrane domain stabilizes the receptor in both the inactive $R G_{G D P}$ state and the active $R^{*} G_{G T P}$ state.

Key words: G-protein-coupled receptors; patch clamp; calcium channels; constitutive activity; receptor states; cannabinoid; tonic activity; $C$ terminal naling (Bouaboula et al., 1997; Vasquez and Lewis, 1999). However, the structural basis of constitutive activity and G-protein sequestration is unknown. A peptide fragment representing the juxtamembrane $\mathrm{C}$-terminal tail of the $\mathrm{CB} 1$ cannabinoid receptor can activate G-proteins (Howlett et al., 1998). We hypothesized that the proximal C-terminal tail of the CB1 cannabinoid receptor is responsible for constitutive activity and that the distal $\mathrm{C}$-terminal tail acts to prevent G-protein activation. We predicted that removal of the distal C-terminal tail (CB1-417) would enhance both the constitutive activity and the ability of the CB1 cannabinoid receptor to sequester G-proteins.

Mutation of aspartate to asparagine in the second transmembrane domain of the CB1 receptor (CB1-D164N) selectively blocked coupling to inwardly rectifying $\mathrm{K}^{+}$channels while leaving coupling to the $\mathrm{Ca}^{2+}$ channels intact (Roche et al., 1999). Thus the CB1-D164N mutation may destabilize G-protein coupling. We therefore hypothesized that the aspartate in the second transmembrane domain of the CB1 receptor plays a crucial role in stabilizing the G-protein-coupled conformation of the receptor. We predicted that the CB1-D164N mutation would destabilize G-protein coupling and block the ability of the CB1 receptor to sequester G-proteins and to adopt a constitutively active conformation. We found that the CB1-D164N mutant receptor was not constitutively active and could not sequester G-proteins. We also found that truncation of the distal $\mathrm{C}$ terminal resulted in a receptor with enhanced constitutive activity and a greater ability to sequester G-proteins.

\section{MATERIALS AND METHODS}

Molecular biological procedures. The human brain cannabinoid receptor CB1 cDNA (from Dr. Tom I. Bonner, Laboratory of Cell biology, National Institute of Mental Health, Bethesda, MD) was subcloned into the mammalian expression vector pCI (Promega, Madison, WI) as de- 
scribed previously (Pan et al., 1996). The C-terminal-truncated CB1-417 receptor was constructed by using PCR techniques to delete amino acids 418-472. To truncate the CB1 receptor, we amplified a DNA segment from a restriction site (StuI) in the middle of the coding sequence of CB1 to the truncation site by PCR via Taq polymerase (Promega). The upstream PCR primer included the StuI site, GTG CGT CAT CCT CCA CTC. A stop codon was included in the downstream primer, CGA GAT CTC GTC AGC CTT CAC AAG AGG GAA AC. The PCR conditions were 30 cycles of $95^{\circ} \mathrm{C}$ for $1 \mathrm{~min}, 50^{\circ} \mathrm{C}$ for $1 \mathrm{~min}$, and $72^{\circ} \mathrm{C}$ for $1.5 \mathrm{~min}$. The PCR product was subcloned into pGEM-T (Promega). Both pCICB1 and the PCR product in pGEM-T were digested with StuI and NotI. The PCR fragment excised from pGEM-T was ligated back into pCI-CB1 to replace the original excised segment and was transformed into JM109 cells (Promega). Colonies were screened for ligation of the PCR fragment by size restriction analysis by using StuI and NotI and were confirmed by sequencing (sequencing facility of the Medical College of Georgia). The mutant CB1 receptor in which the aspartate in the second transmembrane domain was mutated to asparagine, CB1-D164N in pcDNA3, was a gift from Dr. Kenneth Mackie (University of Washington, Seattle, WA). Preparation of plasmid DNA was accomplished with a plasmid prep kit (Qiagen, Santa Clarita, CA).

Neuron preparation and microinjection. Superior cervical ganglion (SCG) neurons were isolated from adult male Wistar rats (350-375 gm) in accordance with National Institutes of Health Guidelines for the Care and Use of Laboratory Animals in Research and approved by the Committee on Animal Use for Research and Education at the Medical College of Georgia. All efforts were made to minimize animal suffering and to use only the number of animals necessary to produce reliable scientific data. Isolated superior cervical ganglia were treated with 0.3 $\mathrm{mg} / \mathrm{ml}$ trypsin, $0.45 \mathrm{mg} / \mathrm{ml}$ collagenase D (Boehringer Mannheim, Indianapolis, IN), and $0.1 \mathrm{mg} / \mathrm{ml}$ DNase in Earle's balanced salt solution for $1 \mathrm{hr}$ at $35^{\circ} \mathrm{C}$ in a shaking water bath. Then the flask was shaken vigorously by hand for $10 \mathrm{sec}$ to dissociate the neurons. Dissociated neurons were plated onto poly-L-lysine-coated $35 \mathrm{~mm}$ culture dishes in MEM (Life Technologies, Gaithersburg, MD) with $10 \%$ fetal calf serum, $1 \%$ glutamine, and $1 \%$ penicillin-streptomycin. Neurons were incubated in a humidified incubator at $37^{\circ} \mathrm{C}$ in $5 \% \mathrm{CO}_{2}$. After $4-5 \mathrm{hr}$ to allow neurons to attach to the culture dishes, CB1, CB1-417, or CB1-D164N plasmid cDNA was microinjected directly into the nucleus of single SCG neurons in concentrations of 50 or $100 \mathrm{ng} / \mu \mathrm{l}$ in water. The pEGFP-N1 plasmid $(10 \mathrm{ng} / \mu \mathrm{l})$ containing the coding sequence of the enhanced green fluorescent protein (Clontech, Palo Alto, CA) was used as a coinjection marker. The plasmid solution was centrifuged $(16,000 \times g)$ in nonheparinized hematocrit tubes for $20 \mathrm{~min}$ to remove suspended debris. Injection pipettes were pulled from fiber-filled capillary glass (1B120F-4; World Precision Instruments, Sarasota, FL) on a P-97 Flaming-Brown micropipette puller (Sutter Instrument, Novato, CA). SCG neurons were microinjected with an Eppendorf 5246 transjector and 5171 micromanipulator (Madison, WI), using an injection pressure of 75-100 $\mathrm{hPa}$ and an injection time of $0.3-0.4 \mathrm{sec}$.

Electrophysiological recording of $\mathrm{Ca}^{2+}$ currents. $\mathrm{Ca}^{2+}$ currents from rat SCG neurons were recorded at room temperature $\left(22-26^{\circ} \mathrm{C}\right) 16-20 \mathrm{hr}$ after injection by the whole-cell variant of the patch-clamp technique (Hamill et al., 1981) with an Axopatch 200A patch-clamp amplifier (Axon Instruments, Foster City, CA). The pipettes for patch recording were pulled from borosilicate glass capillaries (Corning 7052; Garner Glass, Claremont, CA). Patch electrodes were coated with Sylgard 184 (Dow Corning, Midland, MI) and fire-polished on a microforge (Narishige, Tokyo, Japan). Pipette resistances ranged from 2.8 to $3.5 \mathrm{M} \Omega$ when filled with the internal solution described below. The cell membrane capacitance and series resistance were compensated electronically to $>80 \%$. Whole-cell currents were low-pass filtered at $5 \mathrm{kHz}$, using the Bessel filter of the clamp amplifier.

Voltage-clamp protocols were generated with a Power Macintosh 8600/200 computer (Apple Computer, Cupertino, CA) equipped with a PCI-16 Host Interface card connected to an ITC-16 Data Acquisition Interface (Instrutech, Port Washington, NY) using Pulse Control 5.0 extended operations (Richard J. Bookman, Jack D. Herrington, and Kenneth R. Newton, University of Miami, Miami, FL) with IGOR software (WaveMetrics, Lake Oswego, OR). $\mathrm{Ca}^{2+}$ currents were elicited by voltage steps from a holding potential of $-80 \mathrm{mV}$ and digitized at 180 $\mu \mathrm{sec}$ per point. A double-pulse protocol consisting of two $25 \mathrm{msec}$ steps to $+5 \mathrm{mV}$ was used to elicit $\mathrm{Ca}^{2+}$ currents. The first step to $+5 \mathrm{mV}$ elicited the control $\mathrm{Ca}^{2+}$ current. The second step to $+5 \mathrm{mV}$ was preceded by a $50 \mathrm{msec}$ step to $+80 \mathrm{mV}$. The current elicited by the second voltage step to $+5 \mathrm{mV}$ was facilitated when compared with the control current elicited by the first voltage step. Current amplitudes were measured isochronally $10 \mathrm{msec}$ after the first voltage step to $+5 \mathrm{mV}$.

Solutions. To isolate $\mathrm{Ca}^{2+}$ currents for whole-cell recording, we bathed the cells in an external solution that contained (in mM): 140 tetraethylammonium methanesulfonate, 10 HEPES, 15 glucose, 10 $\mathrm{CaCl}_{2}$, and 0.0001 tetrodotoxin, $\mathrm{pH} 7.4$ (adjusted with methanesulfonic acid). The intracellular solution consisted of (in mM): $120 \mathrm{~N}$-methyl-Dglucamine, 20 tetraethylammonium chloride, 10 HEPES, 11 EGTA, 1 $\mathrm{CaCl}_{2}, 4 \mathrm{Mg}$-ATP, $0.1 \mathrm{Na}_{2}-\mathrm{GTP}$, and 14 phosphocreatine, $\mathrm{pH} 7.2$ (adjusted with methanesulfonic acid).

The SF-77B Perfusion Fast-Step device (Warner Instrument, Hamden, CT) was used to apply the cannabinoid receptor agonist WIN 55, 212-2 mesylate (RBI/Sigma, St. Louis, MO), the cannabinoid receptor inverse agonist SR 141716A (a gift from Sanofi-Synthélabo, Paris, France), and the $\alpha_{2}$-adrenergic agonist UK 14304 (RBI/Sigma). Stock solutions of $10 \mathrm{~mm}$ WIN 55,212-2, SR 141716A, and UK 14304 were prepared in dimethylsulfoxide. On the day of the experiment the stock solution of WIN 55,212-2, SR 141716A, and UK 14304 was diluted to 1 $\mu \mathrm{M}$ in external solution and briefly sonicated $(20 \mathrm{sec})$ to facilitate dispersion. This concentration of DMSO in external solution had no effect on the $\mathrm{Ca}^{2+}$ current.

Results are presented as means \pm SEM where appropriate. Statistical significance was determined by Student's $t$ test. The differences were considered significant at $p<0.05$.

\section{RESULTS}

\section{Deletion of the distal C-terminal tail enhances the constitutive activity and the ability of the CB1 cannabinoid receptor to sequester G-proteins}

The C-terminal-truncated CB1-417 receptor in which amino acids 418-472 were deleted was tested for both constitutive activity and G-protein sequestration. Constitutive activity of the CB1 cannabinoid receptor resulted in a tonic inhibition of the voltage-dependent $\mathrm{Ca}^{2+}$ current that was reversed by the CB1 inverse agonist SR 141716A. Both the wild-type CB1 and the truncated $\mathrm{CB} 1-417$ receptors were constitutively active. SR 141716A increased the $\mathrm{Ca}^{2+}$ current in neurons expressing CB1 and CB1-417 cannabinoid receptors (Fig. 1). To compare the constitutive activity between the wild-type CB1 and truncated CB1-417 cannabinoid receptors, we injected two different concentrations of receptor cDNA into the nuclei of SCG neurons. In SCG neurons that were injected with $100 \mathrm{ng} / \mu$ l wild-type CB1 receptor cDNA, SR 141716A increased the $\mathrm{Ca}^{2+}$ current $60.2 \pm$ $13.7 \%(n=10)$. In neurons that were injected with $100 \mathrm{ng} / \mu \mathrm{l}$ CB1-417 cDNA, SR 141716A increased $\mathrm{Ca}^{2+}$ current $110.0 \pm$ $2.3 \%(n=10)$ (Fig. 1). The difference between these groups was not significant $(p=0.08)$. However, in neurons that were injected with $50 \mathrm{ng} / \mu \mathrm{l} \mathrm{CB1-417} \mathrm{cDNA}$, the increase in the $\mathrm{Ca}^{2+}$ current by SR $141716 \mathrm{~A}$ was significantly $(p<0.05)$ greater compared with the wild-type CB1 receptor. SR 141716A increased the $\mathrm{Ca}^{2+}$ current $101.1 \pm 18.9 \%(n=5)$ in neurons that were injected with $50 \mathrm{ng} / \mu \mathrm{l} \mathrm{CB1-417} \mathrm{cDNA}$ compared with $43.1 \pm$ $7.5 \%(n=4)$ in neurons that were injected with $50 \mathrm{ng} / \mu \mathrm{l} \mathrm{CB} 1$ cDNA. These results indicate that at a reduced receptor population the number of C-terminal-truncated CB1-417 receptors that are in a constitutively active state is greater than the number of constitutively active wild-type CB1 receptors. To confirm these results, we tested the effect of the cannabinoid agonist WIN 55,212-2. Previous work has shown that the C-terminal-truncated CB1 receptor has a similar affinity for WIN 55,212-2 (Jin et al., 1999). If the truncated CB1-417 cannabinoid receptor has a greater constitutive activity, then a larger number of the cannabinoid receptor population should be in the active $R^{*} G_{G T P}$ state and a cannabinoid agonist would be predicted to have little additional effect. Inhibition of the $\mathrm{Ca}^{2+}$ current by WIN 55,212-2 
A

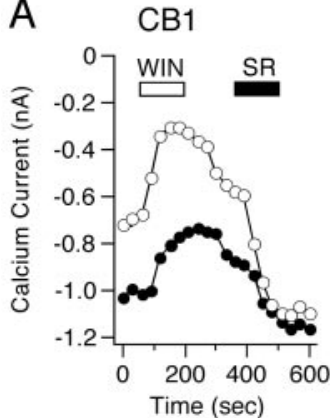

B

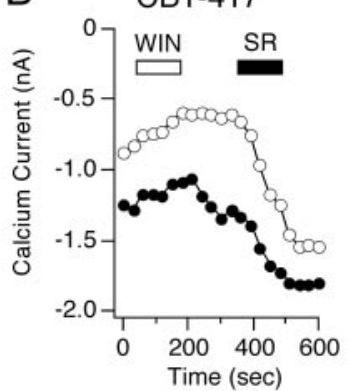

C

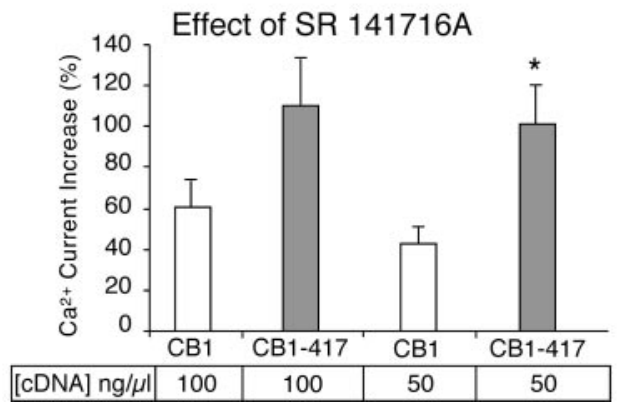

Figure 1. Truncation of the $\mathrm{C}$-terminal tail of the CB1 cannabinoid receptor enhances constitutive activity. $A$, Left, $\mathrm{Ca}^{2+}$ current amplitude is plotted over the time course of the experiment (open circles, amplitude elicited by the first voltage step to $+5 \mathrm{mV}$; filled circles, amplitude from the second step to $+5 \mathrm{mV}$ of a double-pulse protocol shown above the $\mathrm{Ca}^{2+}$ current traces on the right). In an SCG neuron expressing wild-type CB1 receptors (from $100 \mathrm{ng} / \mu \mathrm{l}$ cDNA injection) the application of the cannabinoid agonist WIN 55,212-2 (WIN) decreased the $\mathrm{Ca}^{2+}$ current. Application of the CB1 inverse agonist SR 141716A (SR) increased the $\mathrm{Ca}^{2+}$ current. A, Right, Superimposed current traces in the absence (Control) and presence of $1 \mu \mathrm{M}$ WIN 55,212-2 (WIN) or $1 \mu \mathrm{M}$ SR 141716A (SR). B, Left, In an SCG neuron expressing the C-terminal-truncated CB1-417 receptor (from $100 \mathrm{ng} / \mu \mathrm{l}$ cDNA injection), WIN 55,212-2 produced a small inhibition of the $\mathrm{Ca}^{2+}$ current. A subsequent application of SR 141716A enhanced the $\mathrm{Ca}^{2+}$ current. B, Right, Superimposed current traces in the absence (Control) and presence of WIN 55,212-2 (WIN) or SR 141716A (SR). C, Bar graph of the enhancement of the $\mathrm{Ca}^{2+}$ current in the presence of SR 141716A in SCG neurons that were injected with 100 or $50 \mathrm{ng} / \mu \mathrm{l}$ wild-type CB1 cannabinoid receptor cDNA or truncated CB1-417 receptor cDNA. ${ }^{*} p<0.05$ relative to $50 \mathrm{ng} / \mu \mathrm{l}$ CB1 cDNA injection.

was significantly $(p<0.05)$ smaller in neurons expressing the truncated $\mathrm{CB} 1-417$ receptor (Fig. 1). WIN 55,212-2 (1 $\mu \mathrm{M})$ inhibited the $\mathrm{Ca}^{2+}$ current $43.7 \pm 6.5 \%(n=7)$ in neurons expressing wild-type CB1 receptors compared with $22.6 \pm 3.0$ $(n=5)$ in neurons expressing the truncated CB1-417 receptors (Nie and Lewis, 2001).

As an additional test of the enhanced constitutive activity of the CB1-417 receptor, we tested whether its ability to sequester G-proteins would be enhanced. We have shown previously that the wild-type CB1 cannabinoid receptor can sequester G-proteins and prevent $\alpha_{2}$-adrenergic and somatostatin receptors from signaling (Vasquez and Lewis, 1999). G-protein sequestration occurs because the receptor resides in both an inactive G-proteinprecoupled $R G_{G D P}$ state and a constitutively active $R^{*} G_{G T P}$ state. If the truncated $\mathrm{CB} 1-417$ receptors primarily populate the constitutively active $R * G_{G T P}$ state by depopulating the inactive $R$ state that is uncoupled from G-proteins, then as a population they should be better able to sequester G-proteins and prevent other receptors from signaling. To test this hypothesis, we injected SCG neurons with either 100 or $50 \mathrm{ng} / \mu \mathrm{l} \mathrm{CB} 1$ receptor cDNA and tested for native $\alpha_{2}$-adrenergic receptor signaling. In SCG neurons the $\alpha_{2}$-adrenergic receptor agonist UK 14304 inhibited the $\mathrm{Ca}^{2+}$ current $44.5 \pm 5.7 \%(n=12)$ (Fig. $\left.2 C\right)$. In neurons that were injected with either wild-type CB1 or CB1-417 cDNA (100 $\mathrm{ng} / \mu \mathrm{l})$, the effect of UK 14304 was abolished $(p<0.01)$. UK 14304 inhibited the $\mathrm{Ca}^{2+}$ current only $1.5 \pm 4.2 \%(n=4)$ in neurons expressing $\mathrm{CB} 1$ receptors and $0.2 \pm 2.0 \%(n=5)$ in neurons expressing CB1-417 receptors (Fig. $2 C$ ). However, when the wild-type $\mathrm{CB} 1 \mathrm{cDNA}$ concentration was reduced to $50 \mathrm{ng} / \mu \mathrm{l}$, the effect of the $\alpha_{2}$-adrenergic agonist UK 14304 was partially restored (Fig. 2A,C). UK 14304 inhibited the $\mathrm{Ca}^{2+}$ current $20.0 \pm 3.6 \%(n=4)$ in neurons that were injected with $50 \mathrm{ng} / \mu \mathrm{l}$ CB1 cDNA. In contrast, in SCG neurons that were injected with $50 \mathrm{ng} / \mu \mathrm{l}$ CB1-417 cDNA the UK 14304 still had no effect (Fig. $2 B, C)$. UK 14304 inhibited the $\mathrm{Ca}^{2+}$ current $0.6 \pm 1.2 \%(n=5)$ in neurons that were injected with $50 \mathrm{ng} / \mu \mathrm{l} \mathrm{CB1-417}$ cDNA. These results suggest that the truncated $\mathrm{CB} 1-417$ receptor has an enhanced ability to sequester G-proteins.

The partial restoration of $\alpha_{2}$-adrenergic receptor signaling in neurons that were injected with $50 \mathrm{ng} / \mu \mathrm{l}$ wild-type CB1 cDNA was abolished after the application of the inverse agonist SR 141716A (1 $\mu \mathrm{M})$ (Fig. 2A). SR 141716A traps the CB1 cannabinoid receptor in its inactive $\mathrm{G}$-protein-precoupled $\mathrm{RG}_{\mathrm{GDP}}$ state and prevents the G-proteins from coupling to $\alpha_{2}$-adrenergic receptors. In neurons that were injected with $50 \mathrm{ng} / \mu \mathrm{l} \mathrm{CB1} \mathrm{cDNA}$, the first application of UK 14304 inhibited the $\mathrm{Ca}^{2+}$ current $20.0 \pm 3.6 \%(n=4)$. After application of SR 141716A the UK 14304 inhibited the $\mathrm{Ca}^{2+}$ current only $6.7 \pm 3.0 \%(n=4)$ (Fig. $2 C$ ) in agreement with our previous work (Vasquez and Lewis, 1999). In contrast, in neurons that were injected with $50 \mathrm{ng} / \mu \mathrm{l}$ CB1-417 cDNA, the effect of UK 14304 was no different either before or after SR 141716A. In neurons that were injected with 50 ng/ $\mu$ l CB1-417 cDNA, UK 14304 inhibited the $\mathrm{Ca}^{2+}$ current $0.6 \pm 1.2 \%(n=5)$ before the application of SR 141716A and $0.6 \pm 1.0 \%(n=5)$ after SR 141716A (Fig. $2 C)$.

\section{Mutation of aspartate in the second transmembrane domain of the $\mathrm{CB} 1$ receptor abolishes constitutive activity and G-protein sequestration}

Mutation of aspartate in the second transmembrane domain of the rat CB1 cannabinoid receptor, CB1-D164N, disrupts activation of inwardly rectifying $\mathrm{K}^{+}$channels while leaving $\mathrm{Ca}^{2+}$ channel modulation intact (Roche et al., 1999). Because modulation of both ion channels is mediated by receptor activation of G-proteins, we hypothesized that the D164N mutation impairs G-protein coupling. Wild-type CB1 cannabinoid receptors exist in an inactive G-protein-precoupled $\mathrm{RG}_{\mathrm{GDP}}$ state and a constitutively active $R * G_{G T P}$ state. The wild-type CB1 receptor also is predicted to populate an inactive G-protein-uncoupled $\mathrm{R}$ state. We hypothesized that the D164N mutation destabilizes the receptor such that more of the receptors are in the inactive $\mathrm{R}$ state 

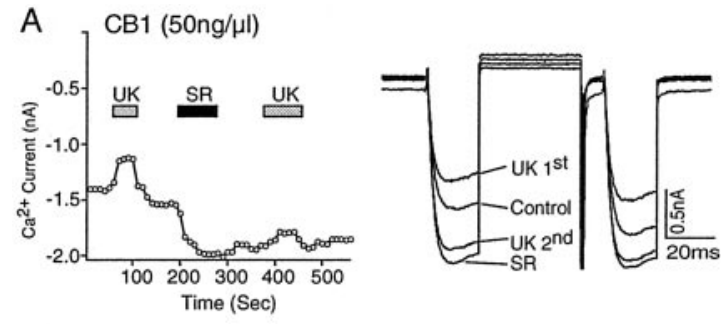

B $\quad$ CB1-417 $(50 \mathrm{ng} / \mathrm{\mu l})$

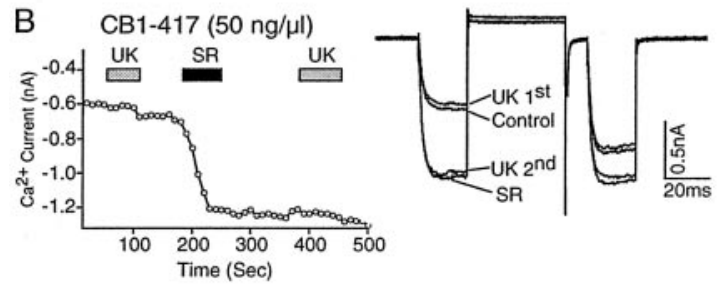

C

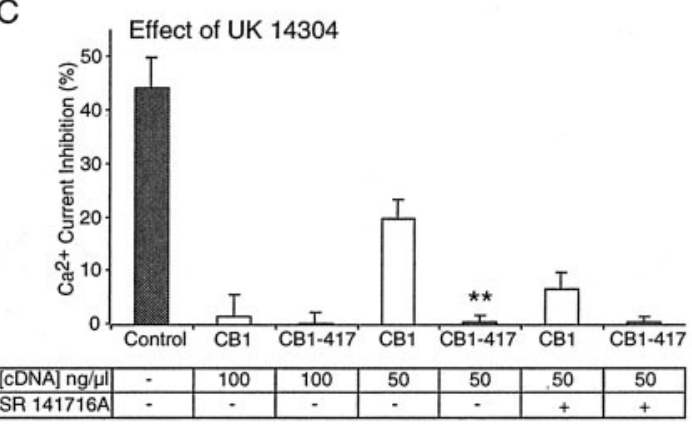

Figure 2. G-protein sequestration is enhanced by truncation of the distal C-terminal tail of the CB1 cannabinoid receptor. A, Left, In an SCG neuron that was injected with $50 \mathrm{ng} / \mu \mathrm{l} \mathrm{CB} 1$, the cDNA application of the $\alpha_{2}$-adrenergic agonist UK 14304 (UK) produced a small inhibition of the $\mathrm{Ca}^{2+}$ current. Application of the CB1 cannabinoid receptor inverse agonist SR 141716A $(S R)$ increased the $\mathrm{Ca}^{2+}$ current and blocked the effect of a subsequent application of UK 14304. A, Right, Superimposed current traces in the absence (Control) and presence of the first and second application of UK 14304 (UK) and SR 141716A (SR). B, Left, In an SCG neuron that was injected with $50 \mathrm{ng} / \mu \mathrm{l}$ CB1-417, cDNA application of UK 14304 had no effect on the $\mathrm{Ca}^{2+}$ current. Application of SR 141716A produced a large increase in the $\mathrm{Ca}^{2+}$ current, and a subsequent application of UK 14304 also had no effect. B, Right, Superimposed current traces in the absence (Control) and presence of the first and second application of UK 14304 (UK) and SR 141716A (SR). C, Bar graph of $\mathrm{Ca}^{2+}$ current inhibition by UK 14304 in neurons expressing wild-type CB1 or truncated CB1-417 receptors from cDNA injections at the concentrations indicated in the table. The effect of UK 14304 in control neurons was abolished in neurons that were injected with $100 \mathrm{ng} / \mu \mathrm{l} \mathrm{CB} 1$ or CB1-417 cDNA. The effect of UK 14304 was partially restored in neurons that were injected with $50 \mathrm{ng} / \mu \mathrm{l} \mathrm{CB1}$, but not with $\mathrm{CB} 1-417$ cDNA. The effect of UK 14304 was abolished after the application of SR $141716 \mathrm{~A}$ for CB1-injected neurons $(50 \mathrm{ng} / \mu \mathrm{l}) .{ }^{* *} p<0.01$ relative to wild-type CB1.

uncoupled from $\mathrm{G}_{\mathrm{i} / \mathrm{o}}$-proteins. Thus we predicted that the mutant CB1-D164N receptor would not be constitutively active and would not sequester G-proteins. If the CB1-D164N receptor is not constitutively active, then the CB1 inverse agonist SR 141716A should have little effect. If the CB1-D164N receptor does not sequester G-proteins, then signaling by the $\alpha_{2^{-}}$ adrenergic receptor should not be affected. In SCG neurons that were injected with CB1-D164N cDNA (100 ng/ $\mu$ l), the cannabinoid agonist WIN 55,212-2 (1 $\mu \mathrm{M})$ inhibited the $\mathrm{Ca}^{2+}$ current (Fig. $3 A$ ) in agreement with the results of others (Roche et al., 1999). $\mathrm{Ca}^{2+}$ current inhibition was similar for both CB1-D164N
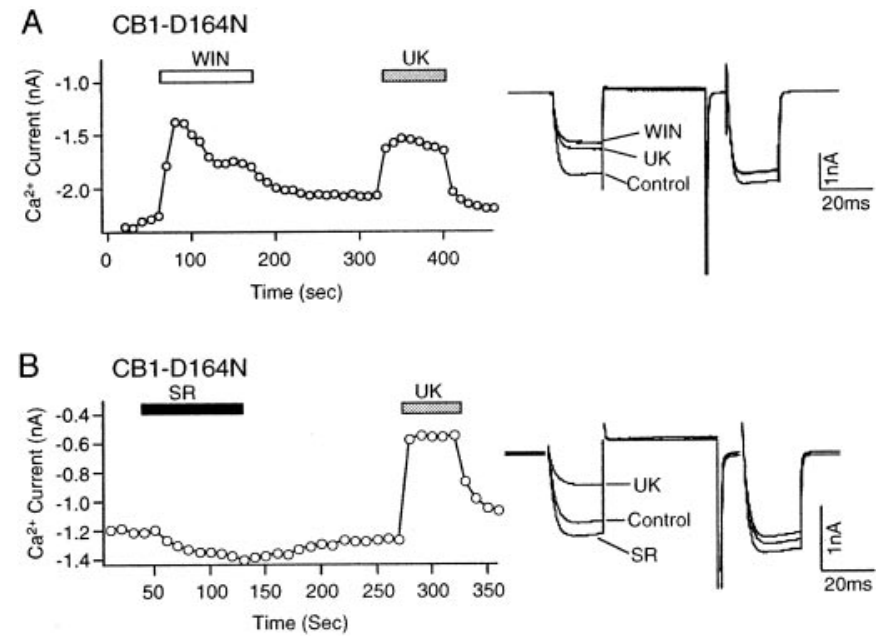

Figure 3. Expression of the mutant CB1-D164N receptor does not interfere with signaling by the $\alpha_{2}$-adrenergic receptor. A, Left, In an SCG neuron that was injected with $100 \mathrm{ng} / \mu \mathrm{l}$ CB1-D164N cDNA, the cannabinoid agonist WIN 55,212-2 $(1 \mu \mathrm{M})$ inhibited the $\mathrm{Ca}^{2+}$ current. In this neuron the effect of WIN 55,212-2 partially desensitized. A subsequent application of the $\alpha_{2}$-adrenergic agonist UK $14304(1 \mu \mathrm{M})$ inhibited the $\mathrm{Ca}^{2+}$ current. A, Right, Superimposed current traces in the absence (Control) and presence of WIN 55,212-2 (WIN) and UK $14304(U K)$. B, Left, In an SCG neuron that was injected with $100 \mathrm{ng} / \mu \mathrm{l} \mathrm{CB1-D164N}$ cDNA, the CB1 inverse agonist SR 141716A $(1 \mu \mathrm{M})$ slightly increased the $\mathrm{Ca}^{2+}$ current. A subsequent application of UK $14304(1 \mu \mathrm{M})$ inhibited the $\mathrm{Ca}^{2+}$ current. B, Right, Superimposed current traces in the absence (Control) and presence of SR 141716A (SR) and UK 14304 (UK).

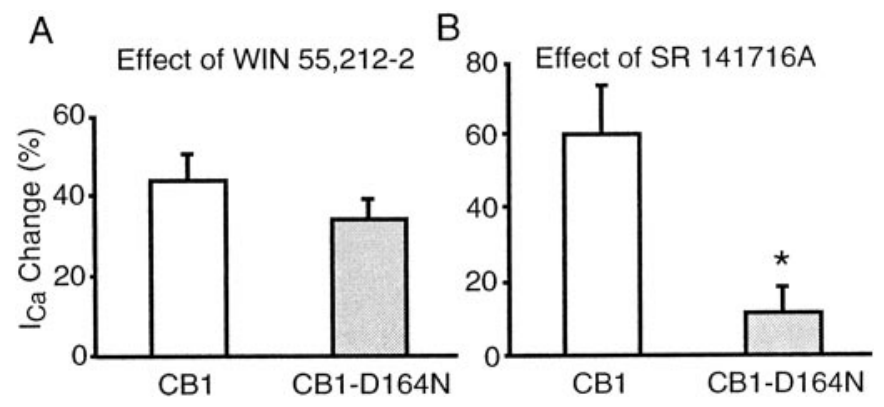

Figure 4. The D164N mutant CB1 receptor is not constitutively active but can be activated by a cannabinoid agonist. $A$, Bar graph of the $\mathrm{Ca}^{2+}$ current inhibition in the presence of the cannabinoid agonist WIN $55,212-2(1 \mu \mathrm{M})$ in neurons that were injected with CB1 or CB1-D164N cDNA $(100 \mathrm{ng} / \mu \mathrm{l}) . B$, Bar graph of the increase in the $\mathrm{Ca}^{2+}$ current by the CB1 inverse agonist SR 141716A in neurons that were injected with wild-type CB1 or CB1-D164N cDNA $(100 \mathrm{ng} / \mu \mathrm{l}) .{ }^{*} p<0.05$ relative to the $\mathrm{CB} 1$ receptor.

and wild-type CB1 receptors. WIN 55,212-2 inhibited the $\mathrm{Ca}^{2+}$ current $34.2 \pm 4.8 \%(n=6)$ in neurons expressing CB1-D164N receptors compared with $43.7 \pm 6.5 \%(n=7)$ in neurons expressing $\mathrm{CB} 1$ receptors (Fig. $4 A$ ). However, unlike for the wild-type CB1 receptors the effect of SR 141716A was abolished $(p<0.05)$ in neurons expressing CB1-D164N receptors. In an SCG neuron expressing CB1-D164N receptors, SR 141716A (1 $\mu \mathrm{M})$ produced a very small increase in the $\mathrm{Ca}^{2+}$ current (Fig. 3B). SR 141716A increased the $\mathrm{Ca}^{2+}$ current $60.2 \pm 13.7 \%(n=10)$ in neurons expressing wild-type CB1 receptors but only by $11.6 \pm 6.9 \%(n=$ 5 ) in neurons expressing CB1-D164N receptors (Fig. 4B). Thus the CB1-D164N receptor does not appear to be constitutively active. 


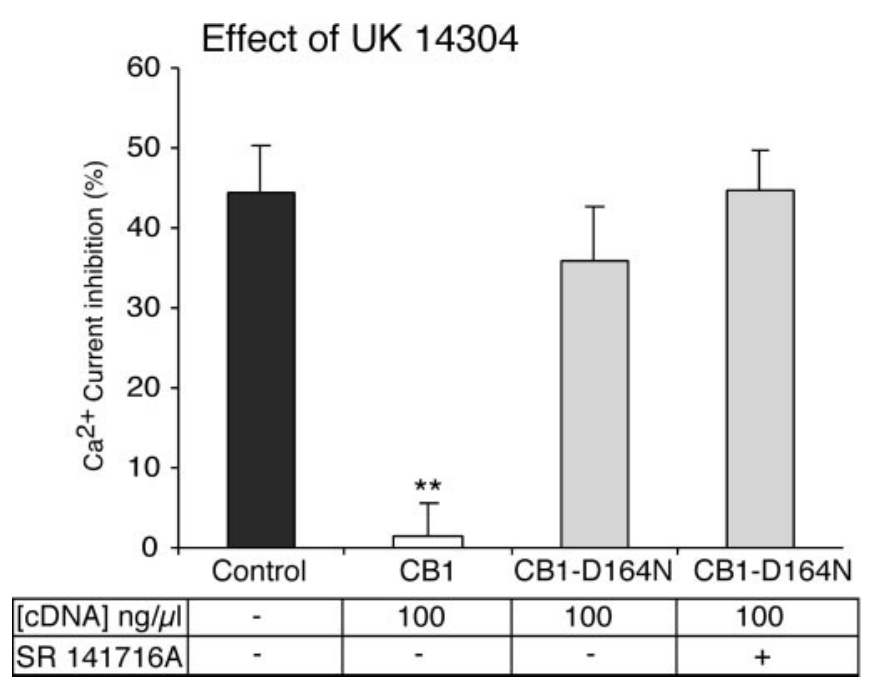

Figure 5. The CB1-D164N cannabinoid receptor does not sequester G-proteins. Bar graph of $\mathrm{Ca}^{2+}$ current inhibition by the $\alpha_{2}$-adrenergic agonist UK 14304 in uninjected control SCG neurons and in neurons expressing wild-type CB1 or CB1-D164N receptors. The effect of UK 14304 was abolished in neurons that were injected with wild-type CB1 receptor cDNA, but not in neurons that were injected with CB1-D164N cDNA. The effect of UK 14304 was no different in neurons expressing CB1-D164N receptors after the application of SR 141716A (1 $\mu \mathrm{M})$. The concentration of receptor cDNA that was injected and the application of SR $141716 \mathrm{~A}$ are indicated in the table. ${ }^{* *} p<0.01$ relative to control neurons or CB1-D164N-injected neurons.

To test whether CB1-D164N receptors can sequester G-proteins, we tested the $\alpha_{2}$-adrenergic agonist UK 14304 in neurons that were injected with $100 \mathrm{ng} / \mu \mathrm{l}$ CB1-D164N cDNA. In SCG neurons expressing CB1-D164N receptors, UK $14304(1 \mu \mathrm{M})$ produced a robust inhibition of the $\mathrm{Ca}^{2+}$ current (Fig. 3). The effect of UK 14304 was no different between uninjected control neurons and neurons that were injected with CB1-D164N cDNA. UK 14304 inhibited the $\mathrm{Ca}^{2+}$ current $44.5 \pm 5.7 \%(n=12)$ in control neurons and $35.8 \pm 6.8 \%(n=5)$ in neurons expressing CB1D164N receptors (100 ng/ $\mu \mathrm{l} \mathrm{cDNA-injected)} \mathrm{(Fig.} \mathrm{5).} \mathrm{In} \mathrm{contrast,}$ UK 14304 had no effect $(1.5 \pm 4.2 \% ; n=4)$ in neurons expressing wild-type CB1 receptors (100 ng/ $\mu$ l cDNA-injected) (Fig. 5). Thus mutation of aspartate in the second transmembrane domain of the $\mathrm{CB} 1$ receptor abolished the ability of the $\mathrm{CB} 1$ receptor to sequester G-proteins and interfere with signaling by the G-protein-coupled $\alpha_{2}$-adrenergic receptor.

G-protein sequestration by the wild-type $\mathrm{CB} 1$ receptor can occur in both inactive $\mathrm{RG}_{\mathrm{GDP}}$ and active $\mathrm{R}^{*} \mathrm{G}_{\mathrm{GTP}}$ receptor conformations (Vasquez and Lewis, 1999). Because the mutant CB1D164N receptor failed to sequester G-proteins, we predicted that this receptor fails to adopt the inactive G-protein-precoupled $\mathrm{RG}_{\mathrm{GDP}}$ conformation. To determine whether the mutant CB1D164N receptor can adopt the inactive G-protein-precoupled $\mathrm{RG}_{\mathrm{GDP}}$ state, we tested the ability of SR 141716 A to stabilize the $\mathrm{RG}_{\mathrm{GDP}}$ state. We have shown previously that SR 141716A acting on the wild-type CB1 receptor can sequester G-proteins by trapping the $\mathrm{CB} 1$ receptor in the $\mathrm{RG}_{\mathrm{GDP}}$ conformation and preventing signaling by the $\alpha_{2}$-adrenergic receptor (Vasquez and Lewis, 1999). SR 141716A failed to abolish the inhibition of the $\mathrm{Ca}^{2+}$ current by the $\alpha_{2}$-adrenergic agonist UK 14304 in neurons expressing CB1-D164N receptors $(100 \mathrm{ng} / \mu \mathrm{l})$. $\mathrm{Ca}^{2+}$ current inhibition by UK $14304(1 \mu \mathrm{M})$ was $35.8 \pm 6.8 \%(n=5)$ before and $44.7 \pm 5.0 \%(n=4)$ after the application of SR 141716A (Fig. 5).
Thus the CB1-D164N receptor, unlike the wild-type CB1 receptor, does not precouple to G-proteins in their inactive $R_{G D P}$ state. These results suggest that the CB1-D164N receptor occupies an inactive state uncoupled from G-proteins but can couple to G-proteins in the presence of the cannabinoid agonist WIN 55,212-2 (Figs. 3A, 4A).

\section{DISCUSSION}

CB1 cannabinoid receptors are constitutively active, which results in a tonic inhibition of $\mathrm{Ca}^{2+}$ channels when expressed in SCG neurons. The CB1 cannabinoid receptors reside in two G-proteincoupled states, a constitutively active $R^{*} \mathrm{G}_{\mathrm{GTP}}$ and an inactive $\mathrm{RG}_{\mathrm{GDP}}$ state (Bouaboula et al., 1997; Vasquez and Lewis, 1999). By stabilizing the inactive $\mathrm{RG}_{\mathrm{GDP}}$ state, the CB1 inverse agonist SR 141716A reverses the constitutive activity by depopulating the active $R * G_{\text {GTP }}$ state. SR 141716 A thus enhances the $\mathrm{Ca}^{2+}$ current in neurons expressing the $\mathrm{CB} 1$ receptors. By stabilizing the inactive $\mathrm{RG}_{\mathrm{GDP}}$ state, $\mathrm{SR} 141716 \mathrm{~A}$ also prevents these G-proteins from interacting with other G-protein-coupled receptors.

In the present study SR 141716A produced a greater enhancement of the $\mathrm{Ca}^{2+}$ current when the distal C-terminal tail of the $\mathrm{CB} 1$ receptor was truncated. When $50 \mathrm{ng} / \mu \mathrm{l} \mathrm{cDNA}$ was injected into SCG neurons, the enhancement of the $\mathrm{Ca}^{2+}$ current in the presence of SR 141716A was significantly $(p<0.05)$ greater for the C-terminal-truncated CB1-417 cannabinoid receptor compared with the wild-type $\mathrm{CB} 1$ receptor. However, when the cDNA injection concentration was $100 \mathrm{ng} / \mu \mathrm{l}$, the enhancement of the $\mathrm{Ca}^{2+}$ current in the presence of SR 141716A approached but was not significantly ( $p=0.08)$ greater for the CB1-417 cannabinoid receptor compared with the wild-type $\mathrm{CB} 1$ receptor. At the $100 \mathrm{ng} / \mu$ l injection concentration both the wild-type CB1 and the C-terminal-truncated $\mathrm{CB} 1-417$ receptor populations are greater; therefore, the number of receptors that are constitutively active is greater. When the receptor density was reduced by injecting $50 \mathrm{ng} / \mu \mathrm{l}$ receptor cDNA, SR 141716A produced a larger increase in the $\mathrm{Ca}^{2+}$ current in neurons expressing CB1-417 receptors compared with wild-type $\mathrm{CB} 1$ receptors. Thus truncation of the distal $\mathrm{C}$-terminal tail of the cannabinoid receptor promotes the constitutively active $R^{*} \mathrm{G}_{\mathrm{GTP}}$ conformational state of the receptor. If a receptor is already in the active $R^{*} G_{\text {GTP }}$ conformation, then the effect of the cannabinoid agonist WIN $55,212-2$, which stabilizes the active $R^{*} G_{G T P}$ state, would be predicted to have little additional effect. Consistent with this prediction, the effect of WIN 55,212-2 on both the $\mathrm{Ca}^{2+}$ channels and the inwardly rectifying $\mathrm{K}^{+}$channels was reduced by truncation of the distal C terminal (Jin et al., 1999; Nie and Lewis, 2001). The distal C-terminal tail of the cannabinoid receptor thus acts to constrain the receptor to its inactive $\mathrm{RG}_{\mathrm{GDP}}$ conformation and slows its transition to the active $R^{*} G_{G T P}$ conformation.

Several other studies on G-protein-coupled receptors also have shown a role for the $\mathrm{C}$ terminal in constitutive activity. Deletion of the $\mathrm{C}$ terminal of the $\beta$-adrenergic receptor enhances its constitutive activity (Parker and Ross, 1991), and the constitutive activity of the D5 dopamine receptor is critically dependent on the C terminal (Demchyshyn et al., 2000). Additionally, shorter C-terminal variants of 5-HT4 receptors have been shown to have greater constitutive activity (Claeysen et al., 1999). Thus, for a subset of G-protein-coupled receptors that show constitutive activity, the C-terminal tail appears to play a critical role in limiting G-protein activation. 
The wild-type CB1 cannabinoid receptor is unusual because it is both constitutively active and it sequesters $\mathrm{G}_{\mathrm{i} / \mathrm{o}}$-proteins, preventing other $\mathrm{G}_{\mathrm{i} / \mathrm{o}}$-coupled receptors from signaling (Vasquez and Lewis, 1999). The $\alpha_{2}$-adrenergic receptor agonist UK 14304 inhibits the $\mathrm{Ca}^{2+}$ current in SCG neurons by activating native $\mathrm{G}_{\mathrm{i} / \mathrm{o}}$-coupled $\alpha_{2}$-adrenergic receptors (Schofield, 1990, 1991). When CB1 cannabinoid receptors are expressed in SCG neurons, the inhibitory effect of the $\alpha_{2}$-adrenergic agonist UK 14304 on the $\mathrm{Ca}^{2+}$ current is abolished. The effect of UK 14304 is abolished because the CB1 cannabinoid receptors sequester a common pool of $\mathrm{G}_{\mathrm{i} / \mathrm{o}}$-proteins (Vasquez and Lewis, 1999). Sequestration of $\mathrm{G}_{\mathrm{i} / \mathrm{o}}$-proteins by the CB1 cannabinoid receptor occurs in both the inactive $R G_{G D P}$ as well as the active $R^{*} G_{G T P}$ conformations (Vasquez and Lewis, 1999).

The results of the present study show that truncation of the distal C-terminal tail of the CB1 cannabinoid receptor enhanced the ability of the receptor to sequester G-proteins. Injection of $100 \mathrm{ng} / \mu \mathrm{l}$ of either CB1 or CB1-417 cDNA abolished signaling by the $\alpha_{2}$-adrenergic receptor. Reducing the cDNA concentration to $50 \mathrm{ng} / \mu \mathrm{l}$ partially restored $\alpha_{2}$-adrenergic receptor signaling in neurons expressing wild-type $\mathrm{CB} 1$ receptors, but not in CB1-417 receptors. Thus deletion of the distal $\mathrm{C}$ terminal of the $\mathrm{CB} 1$ receptor enhanced the ability of the receptor to sequester G-proteins. The opposite effect was obtained by the mutation of aspartate in the second transmembrane domain. The mutant CB1-D164N receptor failed to sequester G-proteins.

Unlike the wild-type CB1 receptor, the mutant CB1-D164N receptor showed little ability to adopt the constitutively active $\mathrm{R}^{*} \mathrm{G}_{\mathrm{GTP}}$ state. The active $\mathrm{R}^{*} \mathrm{G}_{\mathrm{GTP}}$ state causes a tonic inhibition of the $\mathrm{Ca}^{2+}$ current in SCG neurons that is reversed by the CB1 inverse agonist SR 141716A. SR 141716A failed to increase the $\mathrm{Ca}^{2+}$ current in neurons expressing the mutant CB1-D164N receptors, indicating that very few receptors are in the active $\mathrm{R}^{*} \mathrm{G}_{\mathrm{GTP}}$ state. The mutant CB1-D164N receptor also does not precouple to $\mathrm{G}$-proteins in the inactive $\mathrm{RG}_{\mathrm{GDP}}$ state. SR 141716A traps the wild-type CB1 receptor in the inactive $R G_{G D P}$ state, which results in G-protein sequestration and the complete block of $\alpha_{2}$-adrenergic receptor signaling. Signaling by UK 14304 was unaffected by SR 141716A in neurons expressing mutant CB1-D164N receptors. Given that the affinity of SR 141716A is unchanged by the mutation of aspartate to asparagine in the second transmembrane domain (Tao and Abood, 1998), our results suggest that this amino acid plays a critical role in stabilizing both the inactive G-protein-precoupled $R_{G} G_{G D P}$ and the active $\mathrm{R}^{*} \mathrm{G}_{\mathrm{GTP}}$ receptor conformations in the absence of an agonist. However, in the presence of the cannabinoid agonist WIN 55,212-2 the mutant CB1-D164N receptor shows robust G-protein coupling, suggesting that the mutant receptor can undergo the conformational changes to the active $R * G_{G T P}$ conformation.

Previous work has shown that mutation of the aspartate residue in the second transmembrane domain of the CB1 receptor causes it to lose its ability to activate inwardly rectifying $\mathrm{K}^{+}$channels and to inhibit forskolin-stimulated cAMP accumulation, but not its ability to inhibit $\mathrm{Ca}^{2+}$ channels (Tao and Abood, 1998; Roche et al., 1999). Similar results were found for the $\alpha_{2}$-adrenergic receptor. Mutation of the aspartate residue in the second transmembrane domain of the $\alpha_{2}$-adrenergic receptor blocked G-protein coupling to inwardly rectifying $\mathrm{K}^{+}$channels, but not to $\mathrm{Ca}^{2+}$ channels (Surprenant et al., 1990). Our study found that mutation of the aspartate residue in the second transmembrane domain (D2.50) blocked both constitutive activity and the ability of the CB1 receptor to sequester G-proteins. These results suggest that the D2.50 aspartate residue is critical for maintaining a receptor conformation with a high affinity for $\mathrm{G}_{\mathrm{i} / \mathrm{o}}$-proteins in the absence of an agonist. However, because the cannabinoid agonist WIN 55,212-2 is able to activate the mutant CB1-D164N receptor and cause $\mathrm{Ca}^{2+}$ channel modulation, this indicates that the mutant receptor can adopt an agonist-occupied conformational state with high affinity for $G_{i / o}$-proteins. The agonist-occupied G-protein-coupled mutant receptor may select for specific $\mathrm{G}_{\mathrm{i} / \mathrm{o}^{-}}$ proteins that affect $\mathrm{Ca}^{2+}$ channels, but not inwardly rectifying $\mathrm{K}^{+}$channels or adenylyl cyclase.

Mutagenesis studies of several G-protein-coupled receptors indicated an interaction between aspartate (D2.50) and asparagine (N7.49) residues in the second and seventh transmembrane domains that regulate receptor activation (Zhou et al., 1994; Xu et al., 1999; Wilson et al., 2001). However, in the crystal structure of the inactive state of rhodopsin the aspartate (D2.50) and asparagine (N7.49) residues are not close enough to interact directly, but they have an indirect interaction via a bridging water molecule (Palczewski et al., 2000). Modeling studies on the CB1 receptor suggest that aspartate (D2.50) interacts with asparagine (N7.49) only in the active receptor conformation (P. Reggio, personal communication). Our results with the $\mathrm{CB} 1$ receptor suggest that the aspartate residue D2.50 plays a critical role in $\mathrm{G}$-protein binding. The aspartate residue in the second transmembrane domain of the $\mathrm{CB} 1$ receptor allows the receptor the intrinsic flexibility to switch from an inactive state uncoupled to G-proteins into two G-protein-coupled states, an inactive $\mathrm{RG}_{\mathrm{GDP}}$ state responsible for $G_{i / o}$-protein sequestration and an active $R * G_{G T P}$ state responsible for constitutive activity.

In summary, the aspartate-to-asparagine mutation in the second transmembrane domain disrupts G-protein coupling, causing the CB1 cannabinoid receptor to exist primarily in the G-proteinuncoupled $\mathrm{R}$ state. Thus the aspartate in the second transmembrane domain of the CB1 cannabinoid receptor plays a critical role in stabilizing both the inactive $R G_{G D P}$ and the active $\mathrm{R}^{*} \mathrm{G}_{\mathrm{GTP}} \mathrm{G}$-protein-coupled receptor conformations in the absence of agonist. The distal C-terminal tail of the CB1 cannabinoid receptor acts to constrain the receptor from activating G-proteins. Deletion of the distal C-terminal tail promotes the active $\mathrm{R} * \mathrm{G}_{\mathrm{GTP}}$ conformation of the receptor. Thus the aspartateto-asparagine mutation in the second transmembrane domain shifts the CB1 cannabinoid receptor into the G-proteinuncoupled $\mathrm{R}$ state, whereas truncation of the distal $\mathrm{C}$ terminal promotes the constitutively active $R^{*} \mathrm{G}_{\mathrm{GTP}}$ receptor conformation.

\section{REFERENCES}

Bouaboula M, Perrachon S, Milligan L, Canat X, Rinaldi-Carmona M, Portier M, Barth F, Calandra B, Pecceu F, Lupker J, Maffrand JP, Le Fur G, Casellas P (1997) A selective inverse agonist for central cannabinoid receptor inhibits mitogen-activated protein kinase activation stimulated by insulin or insulin-like growth factor 1 . Evidence for a new model of receptor/ligand interactions. J Biol Chem 272:22330-22339.

Claeysen S, Sebben M, Becamel C, Bockaert J, Dumuis A (1999) Nove brain-specific 5-HT4 receptor splice variants show marked constitutive activity: role of the C-terminal intracellular domain. Mol Pharmacol 55:910-920.

Coutts AA, Brewster N, Ingram T, Razdan RK, Pertwee RG (2000) Comparison of novel cannabinoid partial agonists and SR141716A in the guinea-pig small intestine. Br J Pharmacol 129:645-652.

Demchyshyn LL, McConkey F, Niznik HB (2000) Dopamine D5 receptor agonist high affinity and constitutive activity profile conferred by carboxyl-terminal tail sequence. J Biol Chem 275:23446-23455.

Devane WA, Hanus L, Breuer A, Pertwee RG, Stevenson LA, Griffin G, Gibson D, Mandelbaum A, Etinger A, Mechoulam R (1992) Isolation 
and structure of a brain constituent that binds to the cannabinoid receptor. Science 258:1946-1949.

Di Marzo V, Fontana A, Cadas H, Schinelli S, Cimino G, Schwartz J, Piomelli D (1994) Formation and inactivation of endogenous cannabinoid anandamide in central neurons. Nature 372:686-691.

Di Marzo V, Melck D, Bisogno T, De Petrocellis L (1998) Endocannabinoids: endogenous cannabinoid receptor ligands with neuromodulatory action. Trends Neurosci 21:521-528.

Hajos N, Katona I, Naiem SS, MacKie K, Ledent C, Mody I, Freund TF (2000) Cannabinoids inhibit hippocampal GABAergic transmission and network oscillations. Eur J Neurosci 12:3239-3249.

Hamill OP, Marty A, Neher E, Sakmann B, Sigworth FJ (1981) Improved patch-clamp techniques for high-resolution current recording from cells and cell-free membrane patches. Pflügers Arch 391:85-100.

Herkenham M, Lynn AB, Little MD, Johnson MR, Melvin LS, de Costa BR, Rice KC (1990) Cannabinoid receptor localization in brain. Proc Natl Acad Sci USA 87:1932-1936.

Hoffman AF, Lupica CR (2001) Direct actions of cannabinoids on synaptic transmission in the nucleus accumbens: a comparison with opioids. J Neurophysiol 85:72-83.

Howlett AC (1985) Cannabinoid inhibition of adenylate cyclase. Biochemistry of the response in neuroblastoma cell membranes. Mol Pharmacol 27:429-436.

Howlett AC, Fleming RM (1984) Cannabinoid inhibition of adenylate cyclase. Pharmacology of the response in neuroblastoma cell membranes. Mol Pharmacol 26:532-538.

Howlett AC, Song C, Berglund BA, Wilken GH, Pigg JJ (1998) Characterization of CB1 cannabinoid receptors using receptor peptide fragments and site-directed antibodies. Mol Pharmacol 53:504-510.

Jin W, Brown S, Roche JP, Hsieh C, Celver JP, Kovoor A, Chavkin C, Mackie K (1999) Distinct domains of the CB1 cannabinoid receptor mediate desensitization and internalization. J Neurosci 19:3773-3780.

Katona I, Sperlagh B, Sik A, Kafalvi A, Vizi ES, Mackie K, Freund TF (1999) Presynaptically located CB1 cannabinoid receptors regulate GABA release from axon terminals of specific hippocampal interneurons. J Neurosci 19:4544-4558.

Kreitzer AC, Regehr WG (2001) Retrograde inhibition of presynaptic calcium influx by endogenous cannabinoids at excitatory synapses onto Purkinje cells. Neuron 29:717-727.

Landsman RS, Burkey TH, Consroe P, Roeske WR, Yamamura HI (1997) SR141716A is an inverse agonist at the human cannabinoid CB1 receptor. Eur J Pharmacol 334:R1-R2.

Mackie K, Hille B (1992) Cannabinoids inhibit N-type calcium channels in neuroblastoma-glioma cells. Proc Natl Acad Sci USA 89:3825-3829.

Mackie K, Lai Y, Westenbroek R, Mitchell R (1995) Cannabinoids activate an inwardly rectifying potassium conductance and inhibit Q-type calcium currents in AtT20 cells transfected with rat brain cannabinoid receptor. J Neurosci 15:6552-6561.

MacLennan SJ, Reynen PH, Kwan J, Bonhaus DW (1998) Evidence for inverse agonism of SR141716A at human recombinant cannabinoid CB1 and CB2 receptors. Br J Pharmacol 124:619-622.

Matsuda LA, Lolait SJ, Brownstein MJ, Young AC, Bonner TI (1990) Structure of a cannabinoid receptor and functional expression of the cloned cDNA. Nature 346:561-564.

Matsuda LA, Bonner TI, Lolait SJ (1993) Localization of cannabinoid receptor mRNA in rat brain. J Comp Neurol 327:535-550.

Nie J, Lewis DL (2001) The proximal and distal C-terminal tail domains of the CB1 cannabinoid receptor mediate G-protein coupling. Neuroscience, in press.

Ohno-Shosaku T, Maejima T, Kano M (2001) Endogenous cannabinoids mediate retrograde signals from depolarized postsynaptic neurons to presynaptic terminals. Neuron 29:729-738.
Palczewski K, Kumasaka T, Hori T, Behnke CA, Motoshima H, Fox BA, Le Trong I, Teller DC, Okada T, Stenkamp RE, Yamamoto M, Miyano M (2000) Crystal structure of rhodopsin: a G-protein-coupled receptor. Science 289:739-745.

Pan X, Ikeda SR, Lewis DL (1996) Rat brain cannabinoid receptor modulates $\mathrm{N}$-type $\mathrm{Ca}^{2+}$ channels in a neuronal expression system. Mol Pharmacol 49:707-714.

Pan X, Ikeda SR, Lewis DL (1998) SR 141716A acts as an inverse agonist to increase neuronal voltage-dependent $\mathrm{Ca}^{2+}$ currents by reversal of tonic CB1 cannabinoid receptor activity. Mol Pharmacol 54:1064-1072.

Parker EM, Ross EM (1991) Truncation of the extended carboxylterminal domain increases the expression and regulatory activity of the avian $\beta$-adrenergic receptor. J Biol Chem 266:9987-9996.

Roche JP, Bounds S, Brown S, Mackie K (1999) A mutation in the second transmembrane region of the $\mathrm{CB} 1$ receptor selectively disrupts G-protein signaling and prevents receptor internalization. Mol Pharmacol 56:611-618.

Schofield GG (1990) Norepinephrine blocks a calcium current of adult rat sympathetic neurons via an $\alpha 2$-adrenoceptor. Eur J Pharmacol 180:37-47.

Schofield GG (1991) Norepinephrine inhibits a $\mathrm{Ca}^{2+}$ current in rat sympathetic neurons via a G-protein. Eur J Pharmacol 207:195-207.

Shen M, Thayer SA (1998) The cannabinoid agonist Win55,212-2 inhibits calcium channels by receptor-mediated and direct pathways in cultured rat hippocampal neurons. Brain Res 783:77-84.

Stella N, Schweitzer P, Piomelli D (1997) A second endogenous cannabinoid that modulates long-term potentiation. Nature 388:773-778

Sullivan JM (1999) Mechanisms of cannabinoid-receptor-mediated inhibition of synaptic transmission in cultured hippocampal pyramidal neurons. J Neurophysiol 82:1286-1294.

Surprenant A, Shen KZ, North RA, Tatsumi H (1990) Inhibition of calcium currents by noradrenaline, somatostatin, and opioids in guineapig submucosal neurones. J Physiol (Lond) 431:585-608.

Tao Q, Abood ME (1998) Mutation of a highly conserved aspartate residue in the second transmembrane domain of the cannabinoid receptors, CB1 and CB2, disrupts G-protein coupling. J Pharmacol Exp Ther 285:651-658.

Tsou K, Brown S, Sanudo-Pena MC, Mackie K, Walker JM (1998) Immunohistochemical distribution of cannabinoid CB1 receptors in the rat central nervous system. Neuroscience 83:393-411.

Twitchell W, Brown S, Mackie K (1997) Cannabinoids inhibit N- and $\mathrm{P} / \mathrm{Q}$-type calcium channels in cultured rat hippocampal neurons. J Neurophysiol 78:43-50.

Vasquez C, Lewis DL (1999) The CB1 cannabinoid receptor can sequester G-proteins, making them unavailable to couple to other receptors. J Neurosci 19:9271-9280.

Wilson MH, Highfield HA, Limbird LE (2001) The role of a conserved inter-transmembrane domain interface in regulating $\alpha_{2 \mathrm{a}}$-adrenergic receptor conformational stability and cell-surface turnover. Mol Pharmacol 59:929-938.

Wilson RI, Nicoll RA (2001) Endogenous cannabinoids mediate retrograde signaling at hippocampal synapses. Nature 410:588-592.

Xu W, Ozdener F, Li JG, Chen C, de Riel JK, Weinstein H, Liu-Chen LY (1999) Functional role of the spatial proximity of Asp114(2.50) in TMH 2 and Asn332(7.49) in TMH 7 of the mu-opioid receptor. FEBS Lett 447:318-324.

Zhou W, Flanagan C, Ballesteros JA, Konvicka K, Davidson JS, Weinstein H, Millar RP, Sealfon SC (1994) A reciprocal mutation supports helix 2 and helix 7 proximity in the gonadotropin-releasing hormone receptor. Mol Pharmacol 45:165-170. 